\section{从《图解景观生态规划设计原理》 看景观生态规划设计教学中 原理与实践的转化 ILLUSTRATED PRINCIPLES OF LANDSCAPE ECOLOGICAL PLANNING AND DESIGN: TEACHING EXPLORATIONS ON BRIDGING THEORIES WITH PRACTICE OF LANDSCAPE ECOLOGICAL PLANNING AND DESIGN}

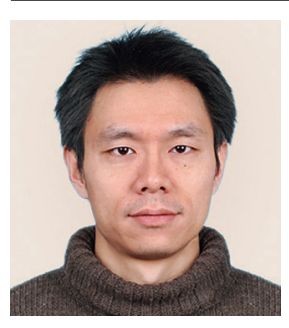

岳邦瑞

西安建筑科技大学建筑学院风景园林系教授、博士生导师

陕西省西安市雁塔区雁塔路13号, 邮编: 710055

417554583@qq.com

YUE Bangrui

Professor and Doctoral Supervisor at Department of Landscape

Architecture in School of Architecture, Xi'an University of

Architecture and Technology

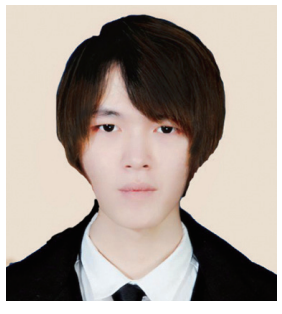

费凡

西安建筑科技大学建筑学院风景园林系博士研究生

FEl Fan

Doctoral Student at Department of Landscape Architecture

in School of Architecture, Xi'an University of Architecture and

Technology
笔者之一的岳邦瑞教授于 2011 年起开始 在西安建筑科技大学建筑学院风景园林系教 授本科与研究生课程, 在对 2011 级本科和研 究生的基础课程进行梳理后, 笔者发现涉及 景观生态学、生态规划设计等学科的既有著 作大多存在体系庞几、内容艰涩两个明显缺
点, 因此希望出版一本零基础读者也可以看 懂的、注重用户体验的原理性教材。至此, 笔者认真思考了景观生态规划设计的理论体 系、规划设计教学与实践之间的关系, 并于 2017年正式出版发行了《图解景观生态规划 设计原理》一书（图1）。该书的内容和呈现
https://doi.org/10.15302/J-LAF-20180509 |收福时间 RECEIVED DATE / 2018-10-08 中图分类号 / TU986 文献标识码/A
摘要

本文围绕《图解景观生态规划设计原理》一书的内容体系，阐述了 作者对于景观生态规划设计的理论、教学与实践体系的思考。本文首先就 将生态学 (及其相关学科) 基本原理应用于景观生态规划设计的研究、教 学与实践方法进行了探索; 随后提出了一个将理论研究与规划设计实践相 桥接的多层次研究体系 (包括基础理论研究、应用基础研究和实践应用研 究 ）；最后，基于上述景观生态规划设计体系建立了以空间导则为核心的 $T-P-C$ 途径 ( 即原理 - 空间格局/空间导则 - 实践案例 ), 并将其作为从 生态学原理到规划设计实践的普适性操作程序。基于对书籍用户的抽样调 查, 本文进一步修订和深化了景观生态规划设计研究体系。

关键词

风景园林学; 生态学; 规划设计; 景观生态学

\section{ABSTRACT}

By reviewing the structure of the book Illustrated Principles of Landscape Ecological Planning and Design, this article reexamines the relationship between theoretical study, teaching, and practice in landscape ecological planning and design. It first explores how to apply the principles of ecological sciences (and other relevant disciplines) into related research, teaching, and practice of landscape ecological planning and design. The authors put forward a multi-level research system that integrates fundamental theories, application bases, and practice, in order to bridge ecological principles with planning and design practice. In addition, based on this landscape ecological planning and design system, the authors developed a T-P-C Approach, a universal operating procedure that links up Theories, Patterns or Principles, and Practice Cases and centers in spatial principles. Through a reader sampling survey, the research system of landscape ecological planning and design is refined and improved based on audience's comments.

\section{KEY WORDS}

Landscape Architecture; Ecology; Planning and Design; Landscape Ecology

基金项目:

陕西省硕士研究生教育综合改革试占项目; 西安建筑科技大学研究生教材建设项目、研究生课程建设 试点项目。

Research Funds:

Prof The Graduate Textbook Improvement Project and the Pilot Project of Graduate Curriculum Improvement of Xi'an University of Architecture And Technology.

整理 余依爽 王胤瑜

译田乐费凡

EDITED BY SHE Yishuang Wang Yinyu

TRANSLATED BY Tina TIAN FEI Fan 


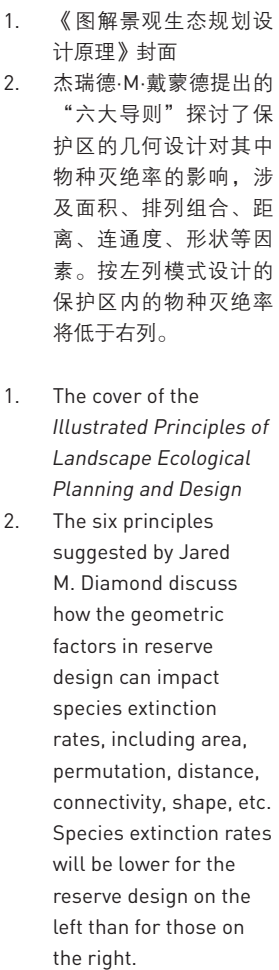

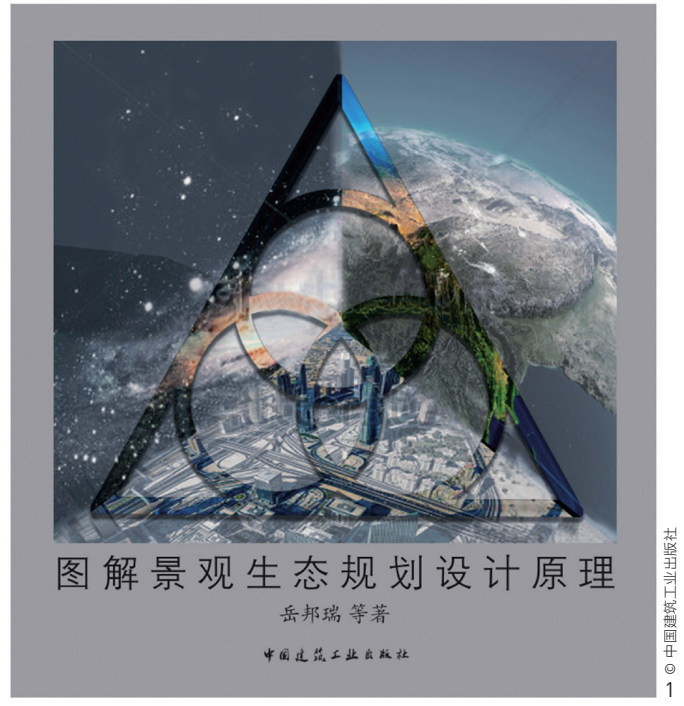

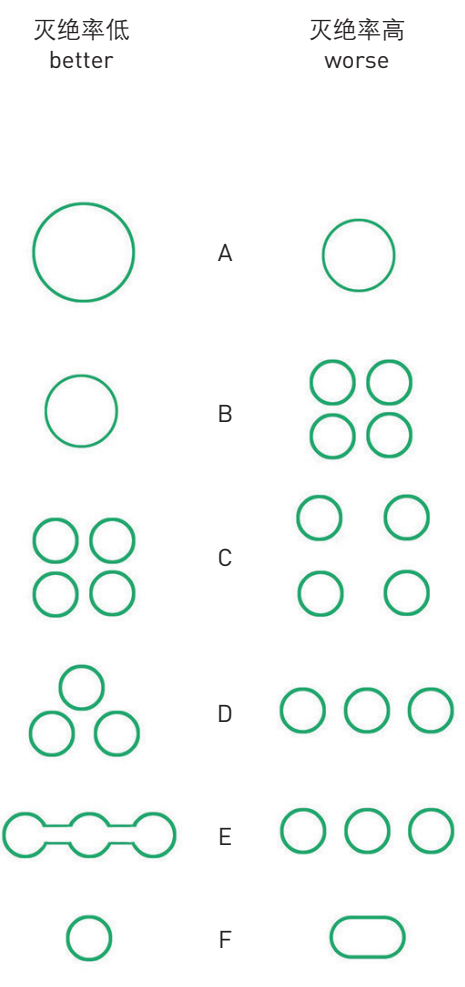

形式主要基于以下思路。

首先, 笔者就将生态学 (及其相关 学科 ) 基本原理应用于景观生态规划设计

(Landscape Ecological Planning and Design, 以下简称LEPD）的研究、教学与实践方法进 行了探索。一方面, 作为LEPD的科学性及基 础性支撑, 对生态学概念、原理与方法的理 解与掌握必不可少; 另一方面, 由于生态学 的理论体系极其庞杂且缺乏落地性, 设计师 和规划师无法直接应用学科知识指导LEPD实 践。换言之, 生态学在长期的发展过程中形 成了一套 “生态学语言体系”, 包括大量的 科学术语、定理、公式、理论、方法等; 而 LEPD使用的则是 “空间设计语言体系” , 表现为土地分区、空间布局、要素组织等内 容。这种 “语言形式” 的差异导致了理论研 究与设计实践之间的断层。

因此, 我们需要建立一个将理论研究
与规划设计实践相桥接的多层次研究体系, 包括基础理论研究、应用基础研究和实践应 用研究：作为根基，基础理论研究涉及的学 科不仅包括生态学, 还有地理学、环境科学 等相关基础学科，其作用在于揭示多种生 态、地理现象的本质与普适性自然规律, 为 LEPD提供坚实的科学理论基础; 实践应用 研究位于顶层, 面向社会生态问题与现实需 要且涵盖多个尺度、类型及领域，主要包括 具体规划设计手法与实践操作程序; 位于中 间层的应用基础研究是衔接生态学原理与规 划设计实践的桥梁，其主要包括建立在基础 理论之上的、面向空间规划设计的各种应用 性理论与方法，包括生态设计原理、地理设 计原理、环境设计原理等。由于这些空间设 计原理须面向实践，因此通常体现为模型、 方法、流程、步骤，以及用于指导实践的策 略、导则、格局、模式、手法与语汇。
随后，笔者基于上述LEPD体系建立了 以 “空间导则” 为核心的 $\mathrm{T}-\mathrm{P}-\mathrm{C}$ 途径, 并 将其作为从生态学原理 (基础理论研究) 到 规划设计实践 (实践应用研究) 的普适性操 作程序。杰瑞德 - M - 戴蒙德根据岛屿生物 地理学原理推导出的6类 “空间导则” ${ }^{[1]}$ (图 2 ) 可进一步归纳为 “同心圆模式” 和 “保 护区网模式” 这两种常用的空间格局, 并应 用于自然保护区的规划实践。笔者由此深受 启发，并借鉴福斯特 - 恩杜比斯的 “过渡性 概念” 思想 ${ }^{[2]}$, 将空间导则视为从原理到实 践的过渡性桥梁, 并在此基础上提出一种更 具普适性的空间设计途径, 即从生态学原理 (Theory) 推导出设计的空间格局 (Pattern) 或空间导则（Principle）, 并最终通过实践 案例 (Case) 进行应用检验与修正 (图3)。 《图解景观生态规划设计原理》一书也体现 了这一推导过程: 该书详细梳理了生态学、 

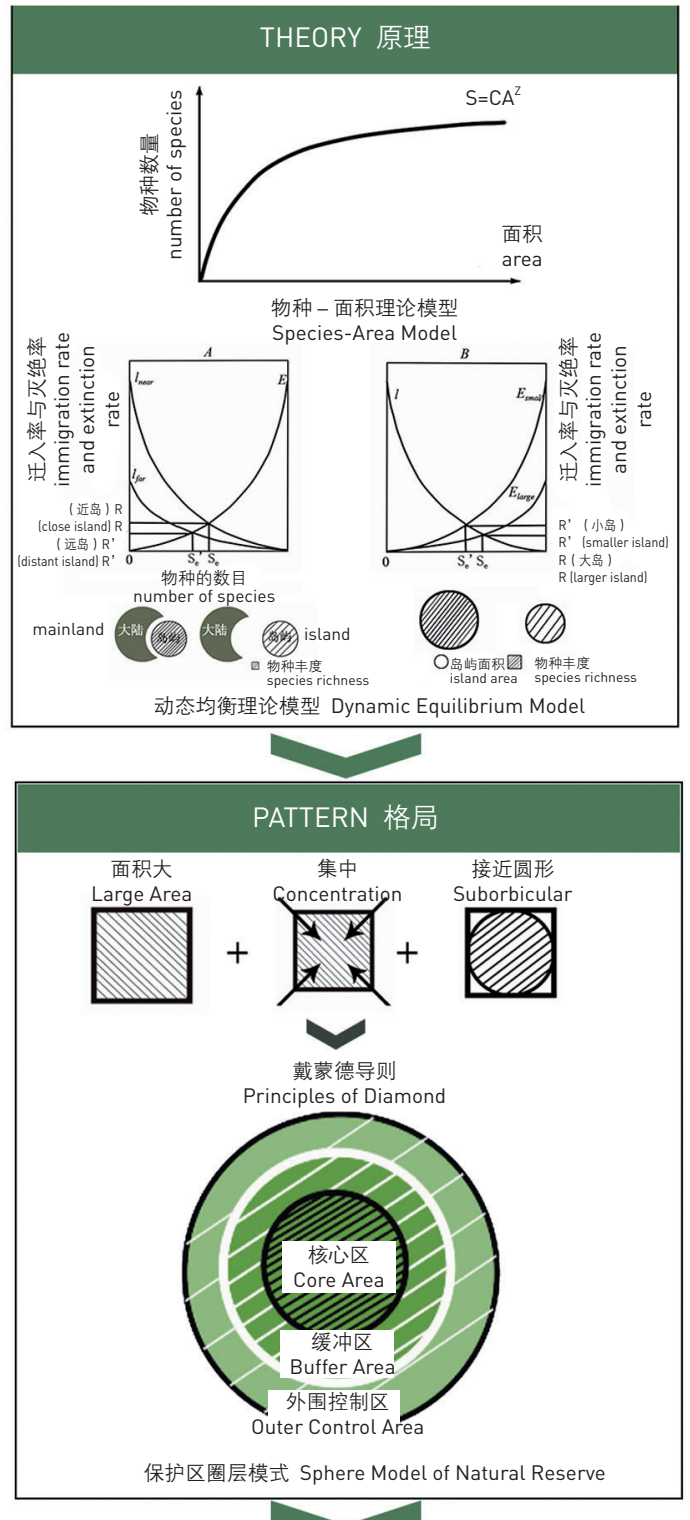

保护区圈层模式 Sphere Model of Natural Reserve

\section{CASE 案例}

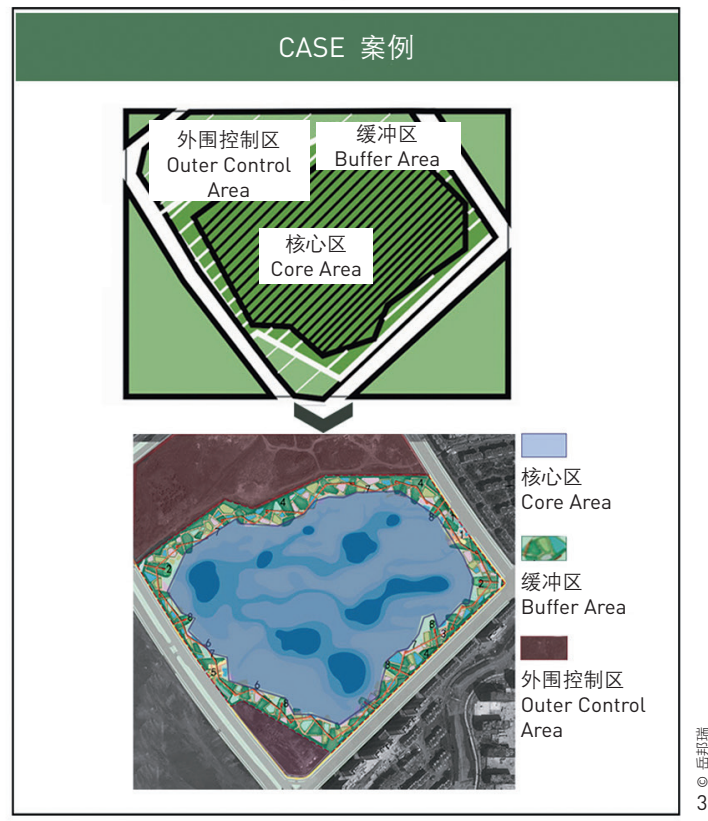

景观生态学、区域与全球生态学的基础理论 体系，遴选出24个可直接应用于空间设计 的知识单元，并逐一对其进行解析和空间转 化, 形成LEPD的原理框架, 进一步通过32个 专题讲解、32个应用案例、100多张表格和 300 多张图解进行深入阐释 ${ }^{[3]}$ 。专题讲解按照 $\mathrm{T}-\mathrm{P}-\mathrm{C}$ 模式编排，将基本理论、空间格局 与导则、实践案例分析展示串联起来, 循序 渐进地呈现了将生态学基本原理应用于规划 设计实践的过程。

《图解景观生态规划设计原理》出版以 来, 既收获了赞誉, 也收到不少批评。笔者 团队通过走访、线上问卷等方式对随机选取 的109位读者进行了意见调查, 并依据读者身 份对反馈中出现频次较高的关键词进行了分
类 (表1)。综合表中意见可知, 本书的逻辑 体系与 $\mathrm{T}-\mathrm{P}-\mathrm{C}$ 途径得到了理解和支持, 但 学生 (尤其是本科生) 认为理论部分较为深 奥, 对案例的解析与应用有着较大兴趣; 科 研人员更关注理论的深度和广度, 认为对部 分理论的探讨浅尝轩止, 以空间格局为核心 的转化途径尚不够全面; 规划师及设计师则 注重从原理到实践的转化与实际操作方法, 认为该部分存在可提升的空间。基于此，笔 者团队进一步完善了对于LEPD研究层次的认 识框架（图4），对三大层次的原有内容进行 了修正, 并在教学过程中对其展开讲解, 以 帮助学生了解研究与实践的关系, 从而理解 并应用LEPD原理。LAF

表1: 《图解景观生态规划设计原理》 读后意见调查 Table 1: Readers' Comments on the Illustrated Principles of Landscape Ecological Planning and Design

\begin{tabular}{|c|c|c|c|c|c|}
\hline $\begin{array}{c}\text { 意见 } \\
\text { Comments }\end{array}$ & $\begin{array}{c}\text { “理论较难理解” } \\
\text { "The theoretical } \\
\text { narrative is abstruse" }\end{array}$ & $\begin{array}{l}\text { “理论深度/广度不足” } \\
\text { "The Spatial Pattern } \\
\text { related exploration is not } \\
\text { comprehensive enough" }\end{array}$ & $\begin{array}{c}\text { “应用途径单一” } \\
\text { "Narrow } \\
\text { applications" }\end{array}$ & $\begin{array}{l}\text { “案例涉域较寉” } \\
\text { "The range of } \\
\text { practice cases is } \\
\text { insufficient" }\end{array}$ & $\begin{array}{l}\text { “案例剖析较浅” } \\
\text { "Case reviews need } \\
\text { to be improved" }\end{array}$ \\
\hline $\begin{array}{c}\text { 在校学生 } \\
\text { College Students }\end{array}$ & • & & & & \\
\hline $\begin{array}{c}\text { 科研人员 } \\
\text { Academic } \\
\text { professionals }\end{array}$ & & & - & $\bullet$ & \\
\hline $\begin{array}{c}\text { 从业人员 } \\
\text { Practitioners }\end{array}$ & $\bullet$ & • & • & $\bullet$ & • \\
\hline
\end{tabular}

注：表中・表示调查项目提及频次, - 越大表示提及频次越高, 空白表示抽样中未提及。

Notes: The dots represent the mentioned frequency of the comments. The larger a dot is, the more the item is mentioned. Blank indicates no mention in sampling.

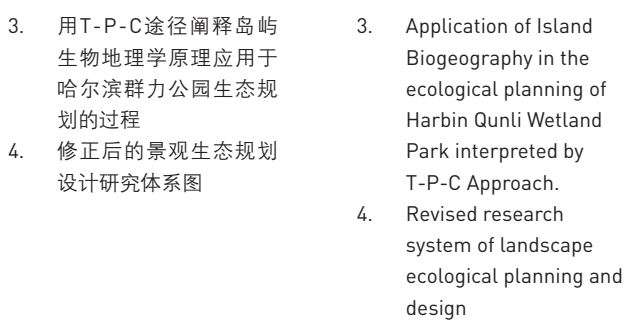




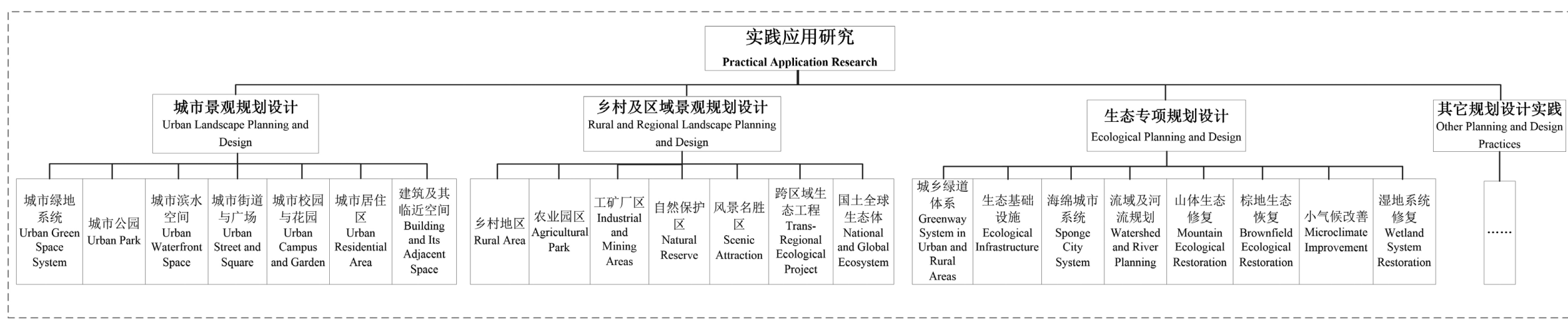

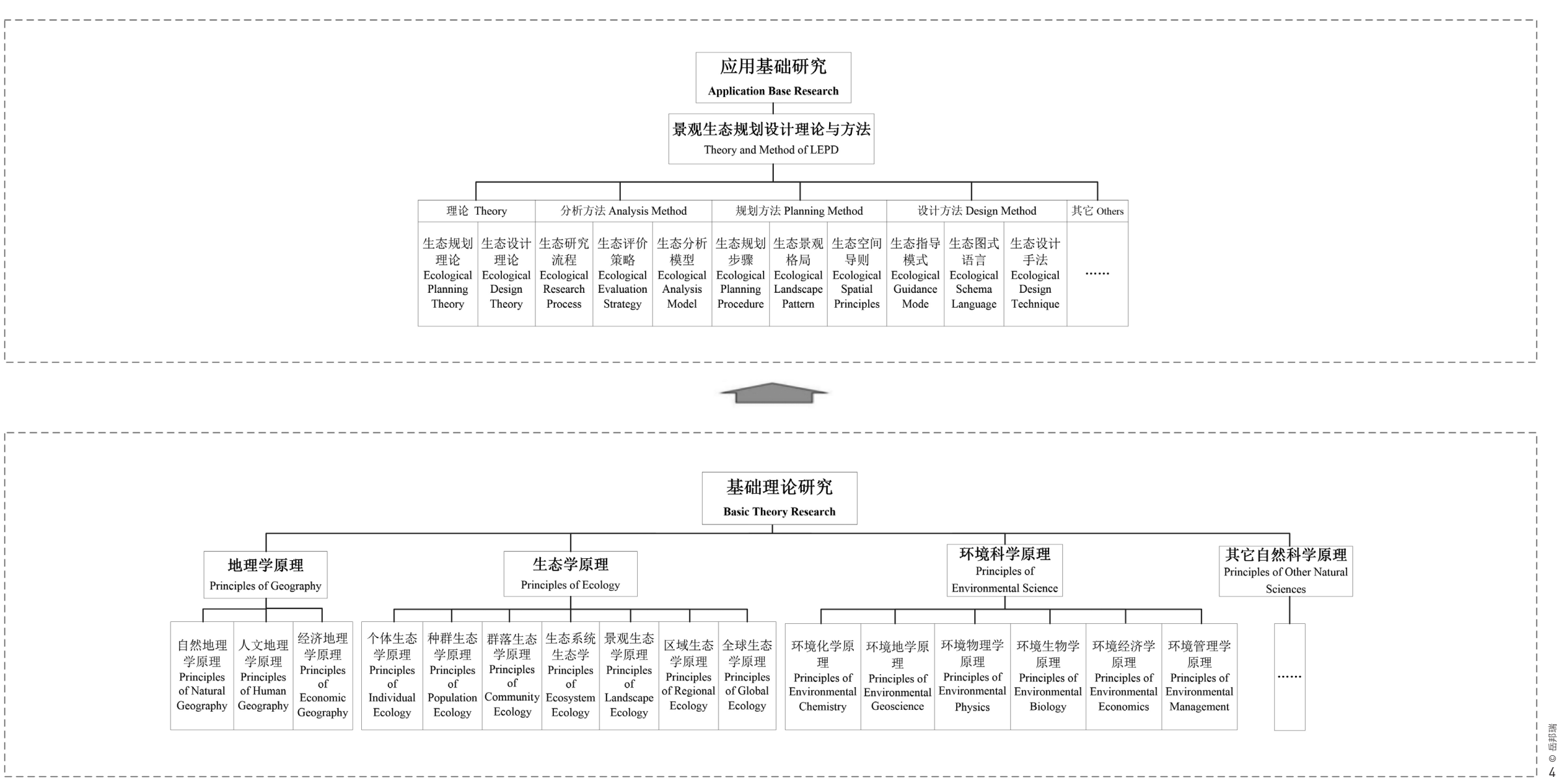


As an instructor for undergraduate and postgraduate programs of Department of Landscape Architecture in School of Architecture, Xi'an University of Architecture and Technology since 2011, Yue Bangrui, one of the authors, argues that most current press works on Landscape Ecology and Ecological Planning and Design involve vast complicated knowledge and are difficult to be understood. With a hope of compiling an entry-level textbook that is intelligible enough for new learners, the authors published the book Illustrated Principles to Landscape Ecological Planning and Design (Fig. 1) in 2017, to reexamine the relationship between theoretical study, teaching, and practice in landscape ecological planning and design. The structure and representation of the book is reviewed in this article.

The authors first explored how to apply the principles of ecological sciences (and other relevant disciplines) into related research, teaching, and practice of landscape ecological planning and design (LEPD hereafter). On one hand, LEPD must be based on ecological sciences, which means that our understanding of ecological concepts, principles, and methods determines how we could apply them; on the other hand, the complicated theoretical system of Ecology makes it difficult to directly instruct LEPD practice. In other words, Ecology itself has developed a "language" that interprets the science with a large number of terms, principles, formulas, theories, and methods; but, LEPD employs another "language" that interprets physical spatial planning and design through territorial zoning, spatial arrangement, element organization, etc. The inconsistency of the both languages results in a series of gaps between theoretical research and real practice.

To bridge LEPD theoretical research with its application, the authors established a multi-level research system that integrates fundamental theories, application bases, and practice. At one end, the level of fundamental theoretical research involves a spectrum of disciplines such as Ecology, Geography, Environmental Science, to reveal the essential principles and universal laws of all kinds of ecological, geographical, and other natural facts, which offer a solid scientific ground for LEPD. At the other end, practice research is to respond to social and ecological problems and demands in reality, which involves specific tangible techniques and procedures in planning and design in a variety of scales, 
types, and fields. Application basis research, as the intermediating level of the system, is expected to bridge ecological principles with planning and design practice by developing theories and methods for spatial application with principles for ecological, geographical, and environmental planning and designs. These principles often see models, methods, processes, and steps, as well as strategies, principles, patterns, approaches, and vocabularies that can be easily translated and applied in spatial planning and design.

Based on this LEPD system, the authors developed a universal operating procedure that combines the principles of Ecology (fundamental theoretical research) with practice of spatial planning and design (practice research) through a T-P-C Approach. Inspired by Jared M. Diamond, who derived six geometric principles from Island Biogeographic studies ${ }^{[1]}$ (Fig. 2), which were further applied in the planning practice of nature reserves by evolving into the "concentric circle pattern" and "network pattern," the authors, by adopting the "transitional concept" by Foster Ndubisi ${ }^{[2]}$, regard spatial principles as bridges to combine theories with practice, and develop a more universal approach to spatial design, which studies theories $(\mathrm{T})$ to derive patterns or principles $(\mathrm{P})$ and then test and revise them through practice cases (C) (Fig. 3). This T-P-C Approach is also reflected in Illustrated Principles to Landscape Ecological Planning and Design. By reviewing the principles of Ecological, Landscape Ecology, Regional and Global Ecology, the book selects 24 knowledge units that can be directly applied in spatial design and translated and reinterpreted into a series of LEPD principles in 32 topics, with 32 cases, over 100 tables, and more than 300 illustrations ${ }^{[3]}$. Among them, these topics are organized in line with the T-P-C Approach, articulating the process that effectively links up fundamental theories, spatial patterns and principles, and practice cases.

The book Illustrated Principles to Landscape Ecological Planning and Design receives both praise and criticism. The authors sampled 109 readers through visits, surveys, and online questionnaires, and extracted hot words and analyzed the comments according to different reader profiles (Table 1): Generally, the logical structure and the T-P-C Approach that the book adopted are commented as "easily understood," but its theoretical narrative is commented as "profound or abstruse" by student audiences (especially undergraduates), who showed a greater interest in the cases parts; Academic professionals commented the theoretical part as "not profound enough" and regarded the spatial pattern related exploration as "incomplete or not comprehensive enough," while showing a greater interest to learn more; Practitioners paid more attention to operational methods that translate principles into practice and commented this part "can be improved." Thanks to such feedbacks, the authors refined and improved the knowledge framework of LEPD research system (Fig. 4). By combining teaching activities, this LEPD system has been explained in details to help students holistically examine and understand the relationship between research and practice to better apply LEPD principles. LAF

\section{REFERENCES}

[1] Diamond, J. M. (1974). Colonization of exploded volcanic islands by birds: the super tramp strategy. Science, (184), 803-806. doi: 10.1126/science.184.4138.803

[2] Ndubisi, F. (2013). Ecological Planning: A Historical and Comparative Synthesis. Beijing: China Architecture \& Building Press.

[3] Yue, B. R., et al. (2017). Illustrated Principles of Landscape Ecological Planning and Design. Beijing: China Architecture \& Building Press. 